\title{
Assessment of Efficacy of Lab-Based Learning in Enhancing Critical Thinking and Creative Thinking Among Learners
}

\author{
Roshee Lamichhane (https://orcid.org/0000-0003-2723-7318) \\ Dipesh Karki (https://orcid.org/0000-0003-4176-3189),
}

\begin{abstract}
With technological innovations happening at workplaces, 21st century organizations demand competencies in thinking creatively and critically. These two skills will potentially help prospective employees become confident individuals, concerned citizens, self-directed learners, and active professionals. In this context, it becomes imperative to overhaul the lecture-based and banking model of the traditional pedagogical approach in order to impart such skills among undergraduate and graduate students. To address this issue, a lab-based teaching-learning method focused on problem-solving and design thinking was introduced at OAMK Labs in Finland. This study assesses the efficacy of lab-based learning in enhancing creativity and critical thinking among students from engineering, management, and science backgrounds of Kathmandu University, Nepal. The study was conducted in a workshop setting using a randomized control trial (RCT) where participants were divided into control and treatment groups. Participants in treatment group took part in a design thinking workshop that applied lab-based learning pedagogy, while those in the control group were given some reading material on improving creativity and critical thinking. Standard tests on both critical and creative thinking in a pre- and post-stages were administered to both groups. Data was analyzed using standard Difference-in-Differences technique. The results showed that while the level of critical thinking improved significantly, among the learners in treatment group alone, the creativity level in the post-stage increased significantly among learners in both groups. Results validated the efficacy of lab-based teaching-learning in addressing the need for critical and creative thinking skills among learners.
\end{abstract}

Keywords: critical thinking, creativity, lab-based learning, innovation, higher education, Difference-inDifferences

\begin{abstract}
Introduction
Due to the recent technological advancements such as automation, robotics, artificial intelligence $(\mathrm{Al})$, and Internet of things (loT), the existing workforce is on the verge of being displaced if they do not acquire requisite skill sets. With this impending threat looming, it becomes imperative that learners of this generation gain life skills that help them stay relevant and productive in the work force. This reality of new workspace requires producing a workforce of independent thinkers, problem solvers, and decision makers (Silva, 2009). Given this backdrop, there is a greater need for learners to prepare themselves with skills sets that can
\end{abstract}

meet the current economic and social world order than the learners of the past centuries (van Laar et al., 2017). These skills are popularly known as 21 st century skills. Despite their popularity, there is no general consensus as to what comprises 21 st century skills. Trilling and Fadel (2009) have grouped 21st century skills as: (i) learning and innovation skills (including critical thinking and problem solving, communication and collaboration, creativity and innovation), (ii) digital literacy skills (including information literacy, media literacy, information and communication literacy), and (iii) career and life skills (including flexibility and adaptability, initiative and self-direction, social and cross- 
cultural interaction, productivity and accountability, leadership and responsibility). Though the definition of 21st century skills may vary, each skill is focused on encouraging learning where one would consider the practicality of use of knowledge and how to apply that knowledge (Larson \& Miller, 2012).

Fischer and Friedman (2015) assert that there are six necessary skills that students need to acquire in order to become indispensable to any organization, principally, the 6Cs:critical thinking, communication, collaboration, creativity, character, and curiosity. These two additional hallmarks of character and curiosity have been added to previous list of the four skills by the 21 st century skills framework created by the American Management Association in 2012.

However, our current education systems have neither evolved in parallel nor in infrastructure, in pedagogical methods, or in curricular material to prepare students for the future workplace (Chu et al., 2017). Most educational institutions in countries like Nepal focus on rote learning that relies more on acquiring and retaining facts and figures and less on fostering analytical thinking (Watkins \& Regmi, 1995).There is a need for new approaches and methods for the teaching-learning process. Soule and Warrick (2015) posit that addressing competencies with a focus on the $4 \mathrm{Cs}$-critical thinking, communication, collaboration, and creativity, as embedded in the Framework of 21stCentury Learning (Casner-Lotto \& Barrington, 2006), requires an updated approach to education which includes a different mindset from the perspectives of many involved in the learning community. Hence, in order to meet the changing needs of 21 st century companies, new learning approaches are required across all fields of study, both nationally and internationally (Wrigley \& Straker, 2015).

The traditional lecture-based method of teaching advocates the banking model of education with a fundamental premise-students are containers and teachers need to fill them with knowledge. This decade-old belief is undoubtedly not adequate to equip and enhance critical skills, reasoning capacity, and creativity among learners (Freire, 1996). In this regard, to improve the innate skills among the learners, various new pedagogies have been proposed, such as (i) case-based learning (Harman et al., 2015), (ii) problem-based learning (Birgili, 2015), and (iii) project-based learning (Sasson et al., 2018). Another addition to this list is the lab-based learning model, which was pioneered in Finland.
This blended model applies a multidisciplinary approach and design thinking process and claims to enhance critical thinking and creativity skills (Heikkinen, 2018).

Several pedagogies have been introduced that supposedly enhance critical thinking and creativity among learners. And to justify this, various methodology have been used. For instance, Musa et al. (2012) used a selfadministered survey questionnaire to show efficacy of project-based learning in improving critical thinking. Similarly, Dillion (2006) in a case study, has shown that working interactively can lead to enhanced creativity. However, so far efficacy of lab-based learning pedagogy in improving critical thinking and creativity among its learners has not been established. Since introducing any new pedagogy entails a cost associated with developing new curriculum, training the faculties and spending resources in terms of money and time, it is essential to evaluate the claims regarding efficacy of the proposed pedagogies in improving theses skills so as to check whether it is worth implementing. In this regard, this research intends to verify the efficacy of the lab-based learning model in improving creativity and critical thinking skills by employing an experimental design method that applies standard proxy variables to measure change in the stated traits. Thus, the study attempts to answer the question, "Does the labbased learning model enhance critical thinking and creativity among learners?"

Further, the paper will provide a future guideline of empirically evaluating the pedagogy's efficacy in improving creativity and critical thinking among its learner using standard quantifiable methods.

\section{Literature Review \\ Need to Integrate 21stCentury Skills in Education}

Because of the rapid growth in technology and change in social and economic conditions, the idea that subject matter taught at school and colleges will be relevant for an entire lifetime of a student is an outdated concept (Schleicher, 2011). In fact, the purpose of education has now shifted to preparation for jobs that have yet to be created, addressing problems that are yet to be known, and using technology that has yet to be invented (Bell, 2016). In this regard, education reformists argue that it is imperative that schools instill and develop within students 21 st century learning skills as the traditional rote form of education is not enough (Jerald, 2009). 21st century skills are considered 
to be a necessary skill set that encompasses life skills, soft skills, and interpersonal skills required for an individual to become competent in the modern work force (Schleicher, 2011). Further, this skill set is essential for the development of non-routine skills that will be more in demand in the future (Murnane, 2008).

Despite 21 st century skills being widely considered as an essential component of future learning, still there is no general consensus on what defines these skills. As a result, the nonprofit organization, Partnership for 21st Century Learning (P21), has collaborated with educators, business leaders, and policymakers in order to define what actually constitutes this skill set (Soule \& Warrick, 2015). Further, according to Soule and Warrick (2015), the 4Cs (critical thinking, communication, collaboration and creativity) are the main skills that would complement core academic subject knowledge. Meanwhile, Binkley et al. (2012) classified 21stcentury skills under four groups: (i) ways of thinking comprised of creativity and innovation, critical thinking, problem solving, decisionmaking, learning to learn, and meta-cognition, (ii) ways of working comprised of communication and collaboration (teamwork), (iii) tools of working comprised of information literacy and information and communication technology literacy, (iv) living in the world comprised of citizenship, local, and global life and career, and personal and social responsibility. Sahin (2009), similarly, categorized 21 st century skills using three subtitles: (i) information and communication skills, (ii) thinking and problem-solving skills, (iii) interpersonal and self-directional skills. Thus, in every classification, critical thinking and creativity have been considered the essential elements of 21st century learning skills.

\section{Critical Thinking Skill}

Critical thinking is defined as "the intellectually disciplined process of actively and skillfully conceptualizing, applying, analyzing, synthesizing, and/or evaluating information gathered from, or generated by observation, experience, reflection, reasoning, or communication, as a guide to belief and action" (Scriven \& Paul, 2007, p. 1). The ability to think critically requires an individual to question and possibly reject accepted ideals and authorities (Antler, 2013). Critical thinking is considered an important life skill and an asset for the future work force (Koenig, 2011). Similarly, Peterson et al. (1997) showed critical thinking as the most important element in medium to high complexity jobs which are defined as those that encompass a wide array of tasks including decision-making, planning, negotiation as well as engineering, and problem-solving. Therefore, improving critical thinking is essential for making an individual, work-place ready.

Higher education is thought to contribute towards critical thinking (McMillan, 1987). In fact, DeAngelo et al. (2009) showed that $99 \%$ of faculties endorsed the importance of critical thinking in undergraduate studies. However, according to Tsui (2002), higher education may not be enough to improve higher order cognitive skills, and hence, in order to improve critical thinking, the pedagogy itself must reflect this need. Among the many pedagogical approaches used to enhance critical thinking, most often the problem-based and project-based learning approaches are used as they put learner's center stage. Bell (2010) opines that project-based learning (PBL) is an innovative approach where students drive their learning through inquiry, collaborative research, and carrying out projects that reflect their knowledge. Further, Musaet al. (2012) have found that PBL, through its focus on investigating problems in the workplace setting, facilitates the growth of critical thinking and creativity skills. Meanwhile, another new line of thought considers critical thinking to be a learned skill that can be engrained in students by actively engaging them in project-based or collaborative activities (Snyder \& Snyder, 2008).

\section{Creativity Skill}

Creativity has many and varied definitions. According to the confluence approach, creativity is considered as the convergence of personality elements that connects ideas, sees similarities and differences, possesses flexibility and aesthetic taste, and is unorthodox, motivated, inquisitive, and questions societal norms (Sternberg, 1999). Recently, the term, creativity, has been coupled with innovation, especially in that creativity is considered the production of novel and useful ideas (Amabile \& Pratt, 2016). Further, creativity requires bipartite aspects, originality and effectiveness, where originality implies novelty in idea and effectiveness refers to a useful fit or appropriateness (Runco \& Jaeger, 2012).

Creativity can also be further divided into the classification of divergent and convergent (Taft \& Rossiter, 1966). The generation of novelty (originality) is considered divergent thinking while effectiveness of an idea is considered convergent thinking. According to Cropley (2006), divergent thinking involves producing multiple answers in unorthodox ways while convergent thinking is 
more orthodox and focuses on indicating one best solution. Therefore, creativity requires a rich mixture of both divergent thinking and convergent thinking in order to avoid reckless changes (Cropley, 2006).

Akin to critical thinking, the need for integrating both forms of creativity in higher education in order to make graduates workplace ready has been advocated for (Sinclaire et al., 2006). In fact, the argument of whether creativity can be amenable to education has a long history, dated back to the ninetieth century (Baer \& Kaufman, 2006). Sinclaire et al. (2006) argues that the prevalence of pressure of quality assurance, a peer review system along with the demand for increased research and efficiency in higher education has led to a decline in creativity. As a result, the pedagogical need of addressing creativity cannot be understated. According to Dillon (2006), inter - and multi-disciplinary learning, collectively called integrativism, in curriculum can enhance creativity among the learners.

Lab-based Model in Learning and Its Role in Enhancing Creativity and Critical Thinking

The lab-based model, developed from a basis of PBL, is a new pedagogical approach considered to enhance 21st century learning skills, specifically, critical thinking and creativity. This Finnish lab-based pedagogical approach, also known as the Lab studio model, is considered to contribute to the learning by applying boundary-crossing, or interdisciplinary skills, resulting in a T-shaped skill base in higher education (Heikkinen, 2018). The lab-based model is, therefore, a multidisciplinary form of the PBL model that utilizes experiences from multiple disciplines including engineering, health sciences, management, and humanities in order to understand and determine a solution for problems from various perspectives. The model uses empathy and reflection to create a bridge to the development of 21 st century skills and core academic knowledge of higher education (Karjalainen et al., 2016).

At its core, the pedagogy of the labbased learning model uses the double diamond design thinking which connects learning with reflective practices, both of which are considered to improve critical thinking and creativity skills (British Design Council, 2005; Hedberg, 2009; Huq \& Gilbert, 2017). The double diamond model that is integrated into the lab-based learning pedagogy is depicted by Figure 1 .

Double Diamond Design

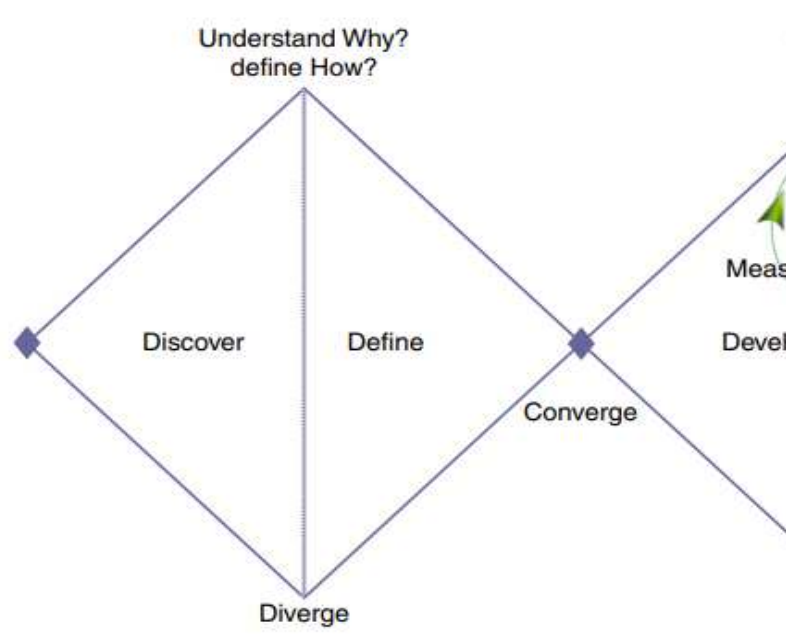

Figure 1. Double Diamond D Note: Adapted from "The double diamond design Design Council, 2005. (https://www.designcouncil. framework-innovation-design-councils-evolv

As shown in Figure 1, the model uses two distinct stages, problem identification and ideation. Within these stages, there is a sequence of discover, define, develop, and deliver activities. Thus, the double diamond model requires a learner to explore any issue or problem both widely and deeply (divergent thinking) which is then partnered with a focused action (convergent thinking). According to Baker et al. (2001), critical thinking is 'convergent' while creative thinking is 'divergent' in nature. Thus, the double diamond model used as the process in the lab-based learning model is meant to enhance both creativity and critical thinking. Additionally, Huq and Gilbert (2017) assert how the double diamond model successfully avoids the traditional push model's practice of telling the students 'what to do' and instead, it challenges the students to co-create a solution to existing problems.

The lab-based learning model, thus, focuses on developing 21st century skills such as communication, collaboration, critical thinking and creativity. However, the effectiveness of the lab-based learning model is yet to be tested through empirical research. This study aims to examine whether the lab-based learning model enhances critical thinking and creativity skills of learners, especially at undergraduate and graduate level students.

\section{Accessing Efficacy of Pedagogy in Enhancing Critical Thinking and Creativity}

Despite the various pedagogical approaches being considered in enhancing both critical thinking and creativity, evaluation of their 
efficacy has produced mixed results. For instance, Terenzini et al. (1995) found that out-ofclass experiences like 'unassigned book readings' increased critical thinking. On the other hand, Arum and Roska (2011) have shown that though the level of critical thinking increases with college, it also declines over time, making college studies less effective in boosting long-term critical thinking.

Scholars agree that the major hindrance of critical thinking is a lack of standardized curricula and a focus on test scores (Landsman \& Gorski, 2007; Sheldon \& Biddle, 1998). Additionally, the assessment of critical thinking takes time and effort as it cannot be measured through standardized testing (Aviles, 1999). According to Bissell and Lemons (2006), subjectindependent tests are the best way to accurately measure critical thinking because these assessments allow measurement of criticalthinking ability regardless of context, thus, allowing comparison between different groups of people (Bissell \& Lemons, 2006). One of the most popular critical assessment techniques is Watson Glaser critical thinking appraisal (CTA) Test which measures different but interdependent aspects of critical thinking that include inferences, recognition of assumptions, deduction, interpretation, and evaluation of arguments (EI Hassan \& Madhum, 2007). A typical question that would be asked is as follows:

"Should companies downsize their workforces to decrease expenses and maximize profits?

Argument: Yes, downsizing will protect the company from bankruptcy in hard economic times. (i) Strong Argument(ii) Weak Argument."

The respondent would need to choose one of the given options. As this type of test is user-friendly and simple to administer, it is widely known to be used by employers (Tips to Pass, n.d.). Watson Glaser CTA Test is used widely in assessing critical thinking in the domain of both the sciences and social sciences (Kumar, 2017; Sadler et al., 2002). Hence, this study will employ Watson Glaser CTA Test to assess whether critical thinking among the learners increased through the use of the lab-based learning model.

Similarly, in the case of enhancing creativity, various assessments of pedagogies have found varied results. For example, Al Hashimi et al. (2019) has indicated that the use of social media can enhance creativity; however, Al Hashimi et al. (2019) have not properly assessed the claim. Meanwhile, Gardiner (2017) opines that creativity declines among learners because of reactive feedback from teachers. But again, the opinion is based more on a belief of teachers rather than actual measurement of the phenomena. In this regard, literature suggests two separate tests for convergent and divergent creative thinking, the Remote Association Test and the Alternative Use Test (Guildford, 1967; Mednick, 1962).

\section{Remote Association Test}

The Remote Association Test (RAT) is a test used to measure creative potential. It was developed by Sarnoff Mednick and Martha Mednick in 1962 and has been considered a valid measure of creativity since then (Mednick, 1962). Each of the RAT questions presents three cue words that are linked by a fourth word, which is the correct answer. For example, "cottage/swiss/cake" is linked by correct answer "cheese". Though the efficacy of the RAT Test in assessing creativity has been challenged on the basis that it focuses on verbal fluency (Ochse \& Van Lill, 1990), a recent study by Lee et al. (2014), using the two-parameter logistics model, has shown RAT to be an effective assessment tool for the Convergent Thinking Test of Creativity.

\section{Alternative Use Test}

The Alternative Use Test introduced by Guildford (1967) is considered a valid test for divergent thinking (Dippo \& Kudrowitz, 2013). It supports the bounded ideation theory that stipulates that a number of novel ideas increases at the beginning of idea generation and then level off as participants become fatigued, forming an Sshaped curve (Reinig et al., 2007). In this alternative user test, the subject is asked questions on the alternative uses of a common object. For example, the test could ask the common uses of a brick. The higher the number of viable alternatives generated, the higher the respondent would score in divergent thinking. This test has been the most widely used in creativity tests (Kim, 1998; Mayer, 1999). It also has a high level of reliability with a correlation above 0.8 (Fink et al., 2010). Since this study aims to evaluate the efficacy of the lab-based learning model in improving critical and creative thinking among learners, all three tests, Watson Glaser CTA Test, Remote Association Test and Alternate Use Test are employed.

\section{Methodology}

This study applies a quasi-experimental method for assessing the impact of the lab-based learning pedagogy in terms of enhancing critical thinking and creativity capacities among learners from the undergraduate and graduate level. To carry out 
the experiment, a randomized control trial (RCT) was designed where participants were divided into either the control or the treatment group. The participants in the treatment group took part in a three-day design thinking workshop held at the Kathmandu University School of Management. The workshop used lab-based learning pedagogy to guide students in critically viewing social problems and creatively finding viable business solutions to solve those problems. Meanwhile, those in the control group were given material to read regarding critical thinking and creativity. The materials focused on understanding and improving the creativity and critical thinking. Participants in both the control and the treatment group were given a pre- and post-assessment,

\begin{tabular}{|l|l|l|l|}
\hline group were given a pre- and post-assessment, & Control group & Treatment Group & Total \\
\hline School of Management & 10 & 12 & 22 \\
\hline School of Engineering & 3 & 11 & 14 \\
\hline School of Science & 0 & 1 & 1 \\
\hline Total & 13 & 24 & 37 \\
\hline
\end{tabular}

Table 1. Distribution of Control and Treatment Group

\begin{tabular}{|l|l|l|l|}
\hline Gender & Control group & Treatment Group & Total \\
\hline Male & 4 & 7 & 11 \\
\hline Female & 9 & 17 & 26 \\
\hline Total & 13 & 24 & 37 \\
\hline
\end{tabular}

Table 2. Distribution of Gender among Control and Treatment Group

consisting of a combination of the Watson Glaser CTA Test, Alternative Use Test and Remote Association Test. As the study made use of human subjects, approval from the research department of Kathmandu University was taken in conformance with the Helsinki 1964 declaration (PP, 1964). The difference in differences econometric method was applied to the scores of creativity and critical thinking obtained during preand post-assessment of participants from both the control and treatment group. This method was applied in order to determine the actual effect of the lab-based learning model on the critical thinking and creativity skill level of participants. The details of the study and the experimental design are explained below.

\section{Study Settings and Participants}

This study draws on the pre- and post-data collected during the three-day "Experimental Boot Camp" workshop, a form of intervention using the lab-based learning model that was held at Kathmandu University School of Management from October 6-9, 2018. First, students from the school of engineering, school of science, and the school of management at Kathmandu University were invited to apply for participation in the workshop online. Prior to registration, all thirtyseven applicants were administered the Watson Glaser CTA Test, Remote Association Test and 
The twenty-four students selected in the treatment group were then mixed with the eight other industry participants that belonged to retail, financial service, startups and software development. Hence, a total of thirty-two participants took part and completed the labbased learning three-day design thinking workshop. During workshop, the participants were provided with several social and environmental issues including improving female hygiene, reducing water pollution, improving computer literacy skills among adults, and reducing sexual harassment at the workplace. The participants from both the industry and students were mixed and grouped into a team and were asked to research on the topic they were given to find viable, desirable and feasible solutions for the issues that could ultimately be turned into a startup business. At the end of the workshop, the teams were asked to present their solution and business plan. The workshop offered participants hands on experience developing new and innovative solutions for addressing social needs. Pedagogically, the workshop was based on the lab-based learning model, originally developed at the Oulu University of Applied Sciences in Finland.

Meanwhile, those who fell into the control group were provided with readings on creativity and critical thinking skills that included "Thinking Fast and Thinking Slow" by Daniel Kahneman and "Steal like an Artist" by Austin Kelon. The readings were provided to simulate traditional classroom-based teaching, and all the learners completed the reading and provided a two-page summary of the content from the readings.

After the workshop, the Watson Glaser CTA Test, Remote Association Test and Alternate Use Test were again administered to both the control and treatment group. The scores were used to compare critical thinking and creativity levels preand post-workshop. It is to be noted that the industry participants were not included in either the pre- or post-assessment as the research only focused on the improvement of the students.

\section{Timing Between Pre and Post Assessment}

According to Brown et al. (2008), a time gap of three to six weeks between the pre-test and post-test is considered ideal as the respondents would only vaguely remember the way they answered the first time the test was taken. In this study, the pre-test was done almost three weeks before the workshop, and hence, aligned with the guidelines given by Brown et al. (2008). Further, the study administered the post assessment the same day as the workshop, as suggested by Lewis \& Lovatt (2013),so as to remove possible confounding errors such as lost interest, absenteeism or fatigue which could have appeared with a delay.

\section{Difference-in-Differences Method for Data Analysis}

The research used a quasiexperimentation design (Meyer, 1995). This was selected to account for false counter-factual information that generally arises while using both a pre- and post-assessment as well as participant and non-participant experimental design. One of the major flaws in the pre versus post design is the lack of a control variable to manage the common trend. As a result of which, counter factual analysis of what would have happened if the intervention had not taken place cannot be assessed. Meanwhile in the case of participant versus non-participant design, the selection process itself can lead to upward bias in the measurement. To overcome these flaws, the research used the difference-in-differences method which combines pre- and postassessment and a participant and non-participant approach to reduce selection bias as well as also the common trend (Lechner, 2011).

The difference-in-differences method, first used by Snow (1854), first stipulates that an intervention and outcome of interest be identified. In this study, the intervention is the workshop using the lab-based learning model, and the outcome of interest is the test scores on creativity and critical thinking. The intervention is then used only with the treatment group while the control group was given a reading task. After the completion of the workshop, a difference in outcome between the treatment and control group in baseline (difference-1) and difference in outcome between both groups post intervention (difference-2) is computed, and finally, the actual impact of intervention is obtained by difference in difference (difference-2 minus difference-1) (Ryan et al., 2015). Thus, the basic outcome can be estimated using the relation as given below: $\mathrm{DD}=(\mathrm{Y}$ treatment-post- $\mathrm{Y}$ treatment-pre $)-(\mathrm{Y}$ control-post-Y control-pre) ........i) where $Y$ is the outcome. 


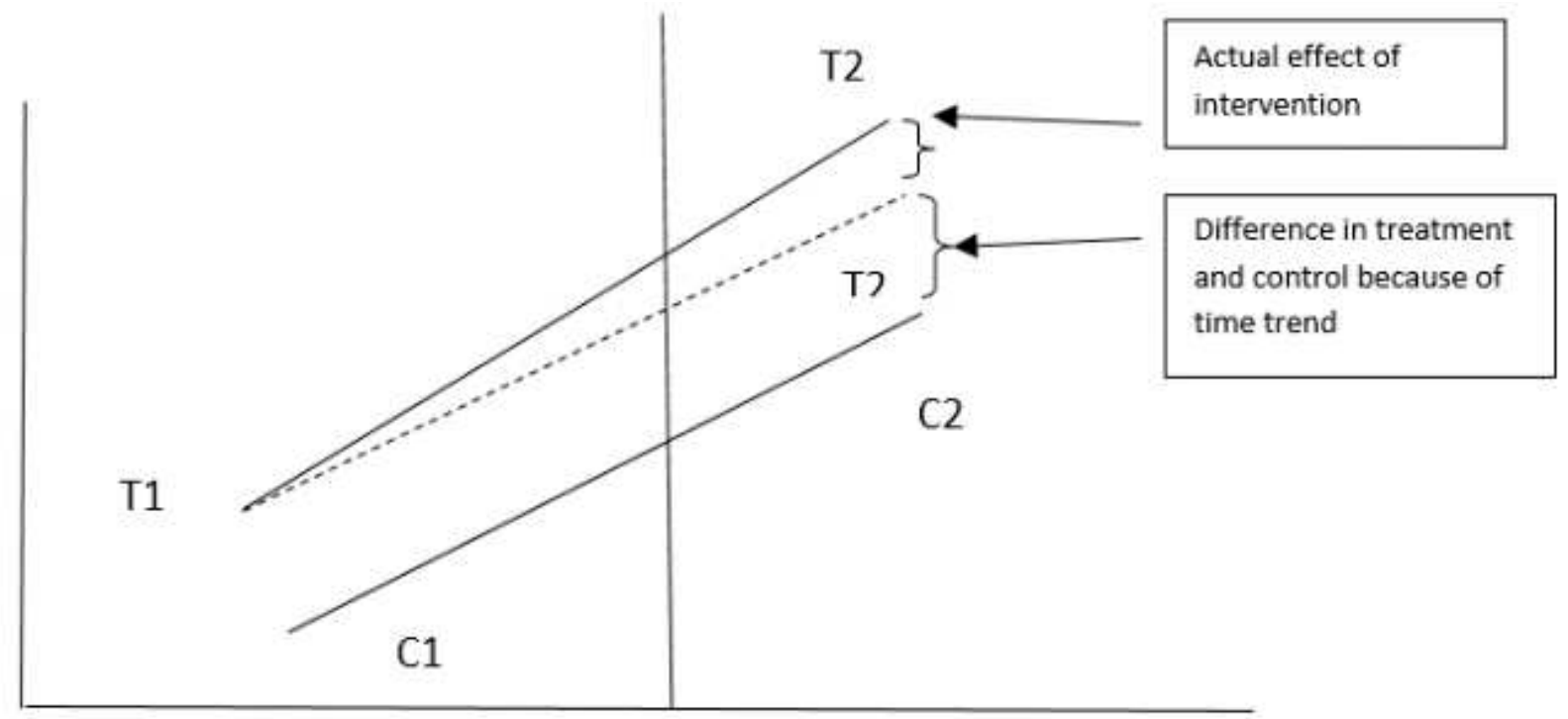

Pre-Intervention

Post-Intervention

Figure 2. Difference-in-Differences Model.

Graphically, it can be represented as shown in Figure 2.

In regression form, difference-in-differences can be represented as:

$\left.Y i=\beta 0+\beta 1 D+\beta 2 P o s t+\beta 3 P_{0 s t}^{*} D \quad \ldots i\right)$

Where:

intervention

Post $=0$ before intervention and 1 after

$D=0$ for control and 1 for treatment treatment

Post $^{\star} \mathrm{D}=$ Interaction between post and

Looking at the regression Coefficient 3

gives the actual intervention impact

$\mathrm{Yi}=$ Score of the students in the

standardized test where $i=1$ is for

creativity and $\mathrm{i}=2$ is for critical thinking

As per Bertrand et al. (2004), the difference-in-differences method is appropriate when interventions are as good as random, conditional, on time, and group fixed effects. In this model, all three requirements were met. The intervention group was randomly selected, only one intervention was done, and the values were derived from the same pool of students. Hence, the methodology was deemed to be sound for use and application.

\section{Flowchart in Research Process}

The overall process of the workshop and the methodology used for the research can be summarized by the flowchart given in Figure 3 . 


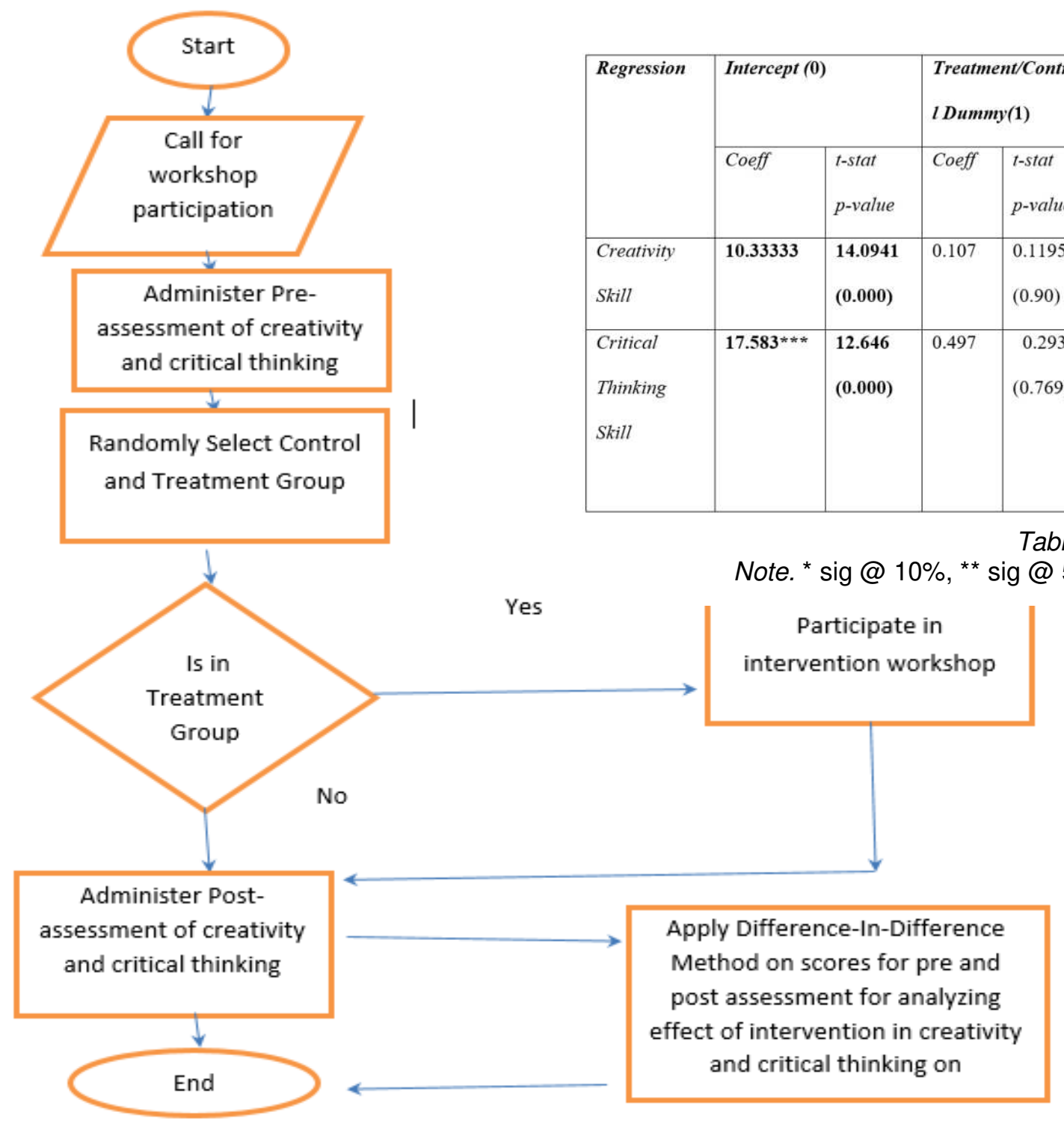

Figure 3. Flowchart of Overall Research.

\section{Results}

After the completion of the workshop, the score from the pre and post assessments of both participants from the control and treatment group were collected and analyzed using the differencein-differences regression given by the equation ii). The results obtained for both critical thinking and creativity skills are tabulated in Table 3. The results show that post-intervention critical thinking skills among students in the treatment group increased by 7 units while the skill of creativity increased by an average 8 units. In the case of creativity, however, the post-analysis showed a rise in creativity by an average of 4 units for both the control and treatment groups. This could perhaps be explained by the fact that, irrespective of selection in control or treatment group, students tried to assess their creativity by using the Internet to learn about these questions. Further, the adjusted $\mathrm{R}$ square value showed that the application of lab-based learning can explain approximately $59 \%$ of variability in the creativity score while the model again explains $47 \%$ variability in the critical thinking score. Further, 
the ANOVA analysis of lab-based learning method's impact on both creativity and critical thinking is highly significant which, in turn, validates the stability of regression equation. Thus, the overall results show that lab-based learning pedagogy does improve creativity and critical thinking among learners of undergraduate and graduate students.

\section{Discussion}

This study has found that lab-based learning pedagogy that uses a double diamond model enhances the critical thinking and creativity among students. This finding is aligned with the opinion of Riggs and Hellyer-Riggs (2014) that critical thinking ability increases among challenged learners as opposed to unchallenged or unreflective learners. Further, as this pedagogy adopts the learning principle of classroom community/co-operative learning and fairness, justice, and equity, it challenges the learners to widen their understanding of the subject matter. According to Elder and Paul (1996), a 'challenged thinker' refers to those who actually are aware of the role that thinking plays in their life and its impact. Since the lab-based pedagogy challenges the learner to come out of their comfort zone and widen their understanding, this increased level of challenge can explain the increase in critical thinking indicated during the post-intervention.

Huq and Gilbert (2017) found that students become more empowered in their learning and will experience a sense of self-awareness if the hierarchical barrier between teachers and students is closed and dissolved. Using the objective self-awareness theory, Silvia and Phillips (2004) have demonstrated that participants' creativity levels drop once they become self-aware of their failures. On the other hand, their creativity levels tend to stabilize if they are not afraid of failure. This phenomenon clearly explains the underlying reason as to why the creativity level registered an improvement in both the control and intervention groups simultaneously. Students were self-aware of their failure of not scoring high in the tests, and hence, performed poorly during the screening phase. But in the post-intervention phase, when students from both the groups were immune from failure as the test was perfunctory, there was a moderate impact on their creativity level. Since lab-based learning pedagogy uses reflective practice and encourages learners to learn from mistakes through feedback and embrace failure, this could well explain the reason behind improvement in the creativity level.
Further, during the workshop, students were asked to write their personal goals on a day-today basis, and they were expected to refine their goals on every succeeding day based on reflection of the preceding day. Moreover, in each stage, learners were asked to self-reflect on their learning and feedback was exchanged among all the learners, both on a peer-review basis and by the lab masters. These iterative reflective practices and self-directed learning is considered to enhance critical thinking (Facione, 2011). In addition to that, Nabhan (2016) and Nesoff (2004) have also found that critical thinking improved through reflective practices such as maintaining journal diaries. Thus, the practice of selfreflection could have been a contributing factor in improving critical thinking among the participants of the workshop in the post-intervention group.

\section{Limitations of the Study}

This study was done among students who chose to voluntarily apply for the workshop which possibly could have led to self-selection bias, as only those students who were interested in design thinking workshop participated. Despite the fact that investigators tried to lessen its impact by randomly choosing the control and treatment groups, assessing its spillover effect into the actual results was rather difficult.

Further, the study used standard creativity tests (Remote Association Test and Alternative Use Test) and a standard critical thinking test (Watson Glaser CTA Test) as the proxy for measuring creativity skills and critical thinking skills. As we cannot rule out the possibility of limitations of the proxies, a better proxy needs to be identified for future studies on the lab-based learning model.

\section{Conclusion}

Creativity, critical thinking, communication, and collaboration are the most sought-after soft skills required for the workforce of the 21st century. However, there is no established pedagogy that attempts to institutionalize them in the teachinglearning process. The lab-based learning model, introduced in the OAMK Labs in Finland, attempts to focus on developing these 4Cs among learners. However, there has been no research carried out to validate the claim. In this context, this research was done to determine whether the lab-based learning model enhances the creativity and critical thinking skills of students. The study conducted, as a part of a three-day workshop based on the lab-based learning model, has shown that, overall, the model improved critical thinking significantly among the treatment group and validates its efficacy. However, in the case of creativity as a skill, the result is a mixed bag as it 
showed to improve in both the control and treatment groups.

\section{References}

Al Hashimi, S., Al Muwali, A., Zaki, Y., \& Mahdi, N. (2019). The effectiveness of social media and multimedia-based pedagogy in enhancing creativity among art, design, and digital media students. International Journal of Emerging Technologies in Learning (iJET), 14(21), 176190.

Amabile, T. M., \& Pratt, M. G. (2016). The dynamic componential model of creativity and innovation in organizations: Making progress, making meaning. Research in Organizational Behavior, 36, 157-183.

Antler, M. (2013). I am a critical thinker: Exploring the relationship between self-concept and critical thinking ability [Undergraduate thesis, University of Central Florida]. https://stars.library.ucf.edu/honorstheses19902015/1381/

Arum, R., \& Roksa, J. (2011). Academically adrift: Limited learning on college campuses. University of Chicago Press.

Aviles, C. B. (1999, March 10 ${ }^{\text {th }}$ - March 13th). Understanding and testing for "critical thinking" with bloom's taxonomy of educational objectives [Paper Presentation]. Council on Social Work Education $45^{\text {th }}$ Annual Conference, San Francisco, California.

Baer, J., \& Kaufman, J. C. (2006). Creativity research in English-speaking countries. In J. C. Kaufman, \& R. J. Sternberg (Eds.), The international handbook of creativity.

Baker, M., Rudd, R., \& Pomeroy, C. (2001). Relationships between critical and creative thinking. Journal of Southern Agricultural Education Research, 51(1), 173-188.

Bell, D. V. (2016). Twenty-first century education: Transformative education for sustainability and responsible citizenship. Journal of Teacher Education for Sustainability, 18(1), 48-56.

Bell, S. (2010). Project-based learning for the $21^{\text {st }}$ century: Skills for the future. The Clearing House: A Journal of Educational Strategies, Issues and Ideas, 83(2), 39-43. https://doi.org/10.1080/00098650903505415

Bertrand, M., Duflo, E., \& Mullainathan, S. (2004). How much should we trust differences-indifferences estimates? The Quarterly Journal of Economics, 119(1), 249-275.

Binkley, M., Erstad, O., Herman, J. Raizen, S., Ripley, M., Miller-Ricci, M., \& Rumble, M. (2012). Defining twenty-first century skills. Assessment and Teaching of 21st Century Skills, 17-66.
Bissell, A. N., \& Lemons, P. P. (2006). A new method for assessing critical thinking in the classroom. BioScience, 56(1), 66-72.

Birgili, B. (2015). Creative and critical thinking skills in problem-based learning environments. Journal of Gifted Education and Creativity, 2(2), 71-80.

British Design Council. (2005). The double diamond design process model.https://www.designcouncil.org.uk/newsopinion/what-framework-innovation-designcouncils-evolved-double-diamond

Brown, G., Irving, S., \& Keegan, P. (2008). An introduction to educational assessment, measurement, and evaluation: Improving the quality of teacher-basedassessment. Pearson Education.

Casner-Lotto, J., \& Barrington, L. (2006). Are they really ready to work? Employers' perspectives on the basic knowledge and applied skills of new entrants to the 21st century US workforce. Partnership for 21st Century Skills Chu, S. K. W., Reynolds, R. B., Tavares. N. J., Notari, M., \& Lee, C. W. Y. (2017).

$21^{\text {st }}$ century skills development through inquirybased learning: From theory to practice. Springer. Cropley, A. (2006). In praise of convergent thinking. Creativity Research Journal, 18(3), 391404.

DeAngelo, L., Hurtado, S., Pryor, J. H., Kelly, K. R., Santos, J. L., \& Korn, W. S. (2009). The American college teacher: National norms for the 2007-2008 HERI faculty survey. Higher Education Research Institute.

Dillon, P. (2006). Creativity, integrativism and a pedagogy of connection. Thinking Skills and Creativity, 1(2), 69-83.

Dippo, C., \& Kudrowitz, B. (2013, April 11-13). Evaluating the alternative use test of creativity. Proceedings of the National Conference on Undergraduate Research, University of Wisconsin, La Crosse, WI.

Elder, L., \& Paul, R. (1996). Critical thinking: A stage theory of critical thinking: Part I. Journal of Developmental Education, 20(1), 34.

El Hassan, K., \& Madhum, G. (2007). Validating the Watson Glaser critical thinking appraisal. Higher Education, 54(3), 361-383.

Facione, P. A. (2011). Critical thinking: What it is and why it counts. Insight Assessment, 2007(1), 1-23.

Fink, A., Grabner, R. H., Gebauer, D., Reishofer, G., Koschutnig, K., \& Ebner, F. (2010). Enhancing creativity by means of cognitive stimulation: Evidence from an FMRI study. Neurolmage, 52(4), 1687-1695. 
Fischer, D., \& Friedman, H. H. (2015, August 20). Make yourself indispensable: Skills employers desperately need to succeed in the knowledge economy.

Papers.

https://papers.ssrn.com/sol3/papers.cfm?abstrac $\mathrm{t}$ id=2648691

Freire, P. (1996). Pedagogy of the oppressed (revised). The Continuum International Publishing Group Inc.

Gardiner, P. (2017). Rethinking feedback: Playwriting pedagogy as teaching and learning for creativity. Teaching and Teacher Education, 65, 117-126.

Gajda, R. (2004). Utilizing collaboration theory to evaluate strategic alliances. American Journal of Evaluation, 25(1), 65-77.

Harman, T., Bertrand, B., Greer, A., Pettus, A., Jennings, J., Wall-Bassett, E., \& Babatunde, O. T. (2015). Case-based learning facilitates critical thinking in undergraduate nutrition education: Students describe the big picture. Journal of the Academy of Nutrition and Dietetics, 115(3), 378388.

Hedberg, P. R. (2009). Learning through reflective classroom practice: Applications to educate the reflective manager. Journal of Management Education, 33(1), 10-36.

Heikkinen, K.-P. (2018). Exploring studio-based higher education for T-shaped knowledge workers, case $L A B$ studio model [Unpublished Doctoral Dissertation]. University of Oulu.

Huq, A., \& Gilbert, D. (2017). All the world's a stage: transforming entrepreneurship education through design thinking. Education + Training, 59(2), 155-170.

https://doi.org/10.1108/et-12-2015-0111

Jerald, C. D. (2009). Defining a 21st century education. Center for Public Education.

Karjalainen, J., Seppänen, U-M., \& Heikkinen, KP. (2016). Oamk LABs practices for bridging work life 21 th century skills and higher education. UAS Journal.

https://www.theseus.fi/bitstream/handle/10024/1 24103/Karjalainen Oamk\%20LABs\%20.pdf Koening, J. A. (2011). Assessing 21st century skills: Summary of a workshop. National Academies Press.

Kim, Y. (1998). The Torrance tests of creative thinking norms: Technical manual of Korean version. Chung Ang Aptitude Press.

Kumar, R. R. (2017). Effectiveness of formal logic course on the reasoning skills of students in Nizwa College of Technology, Oman. Journal of Education and Practice, 8(7), 30-35.
Landsman, J., \& Gorski, P. (2007). Countering standardization. Educational Leadership, 64(8), 40-41.

Larson, L. C. \& Miller, T. N. (2012). $21^{\text {st }}$ century skills: Prepare students for the future. Kappa Delta Pi Record, 47(3), 121-123.

Lechner, M. (2011). The estimation of causal effects by difference-in-difference methods. Foundations and Trends in Econometrics, 4(3), 165-224.

Lee, C. S., Huggins, A. C., \& Therriault, D. J. (2014). A measure of creativity or intelligence? Examining internal and external structure validity evidence of the Remote Associates Test. Psychology of Aesthetics, Creativity, and the Arts, 8(4), 446-460.

Lewis, C., \& Lovatt, P. J. (2013). Breaking away from set patterns of thinking: Improvisation and divergent thinking. Thinking Skills and Creativity, 9, 46-58.

Mayer, R. E. (1999). Fifty years of creativity research. Cambridge University Press

McMillan, J. H. (1987). Enhancing college students' critical thinking: A review of studies. Research in Higher Education, 26, 3-29. https://doi.org/10.1007/BF00991931

Mednick, S. A. (1962). The associative basis of the creative process. Psychological Review, 69, 220 -232.https://doi.org/10.1037/h0048850

Meyer, B. D. (1995). Natural and quasiexperiments in economics. Journal of Business \& Economic Statistics, 13(2), 151-161.

Murnane, J. (2008). Preparing to thrive in 21st century America. Presentation to the Mobile Area Education Foundation.

Musa, F., Mufti, N., Latiff, R. A., \& Amin, M. M. (2012). Project-based Learning (PjBL): Inculcating soft skills in $21^{\text {st }}$ century workplace. Procedia Social and Behavioral Sciences, 59, 565-573.

Nabhan, S. (2016, March 13). Students' journal writing: Promoting reflective learning on students' perception and comprehension towards students' self-awareness and critical thinking development in English as foreign language classroom [Conference session]. 7th International Conference on Educational Technology of Adi Buana (ICETA-7).

Nesoff, I. (2004). Student journals: A tool for encouraging self-reflection and critical thought. Journal of Baccalaureate Social Work, 10(1), 46-60.

Ochse, R., \& Van Lill, B. (1990). A critical appraisal of the theoretical validity of the Mednick remote association test. South African Journal of Psychology, 20(3), 195-199. 
Peterson, N. G., Mumford, M., Borman, W., Jeanneret, P., Fleishman, E., \& Levin, K. (1997). $O * N E T$ final technical report. Utah Department of Workforce Service.

PP, R. (1964). Human experimentation. Code of ethics of the world medical association. Declaration of Helsinki. British Medical Journal, 2(5402), 177-177.

Reinig, B. A., Briggs, R. O., \& Nunamaker, J. F. (2007). On the measurement of ideation quality. Journal of Management Information System, 23(4), 143-161.

Riggs, L. W., \& Hellyer-Riggs, S. (2014). Development and motivation in/for critical thinking. Journal of College Teaching \& Learning (TLC), 11(1), 1-8. https://doi.org/10.19030/tlc.v11i1.8391

Runco, M. A., \& Jaeger, G. J. (2012). The standard definition of creativity. Creativity Research Journal, 24(1), 92-96.

Ryan, A. M., Burgess, J. F., \& Dimick, J. B. (2015). Why we should not be indifferent to specification choices for difference in differences. Health Services Research, 50(4), 1211-1235.

Sadler, T. D., Chambers, F. W., \& Zeidler, D. L. (2002, April). Investigating the crossroads of socio-scientific issues, the nature of Science, and critical thinking[Paper Presentation] National Association for Research in Science Teaching Annual Meeting, New Orleans.

Sahin, M. C. (2009). Instructional design principles for $21^{\text {st }}$ century learning skills. Procedia Social and Behavioral Sciences, 1, 1464-1468.

Sasson, I., Yehuda, I., \& Malkinson, N. (2018). Fostering the skills of critical thinking and question-posing in a project-based learning environment. Thinking Skills and Creativity, 29, 203-212.

Schleicher, A. (2011). The case for 21st century learning. OECD Observer, 282, 42-43.

Scriven, M., \& Paul, R. (2007). Defining critical thinking. The Foundation for Critical Thinking. http://www.criticalthinking.org/aboutCT/define $\mathrm{cr}$ itical thinking.cfm

Sheldon, K. M., \& Biddle, B. J. (1998). Standards, accountability, and school reform: Perils and pitfalls. Teachers College Record, 100(1), 164180.

Silva, E. (2009). Measuring skills for $21^{\text {st }}$ century learning. The Phi Delta Kappan, 90(9), 630-634.

Silvia, P. J., \& Phillips, A. G. (2004). Selfawareness, self-evaluation, and creativity. Personality and Social Psychology Bulletin, 30(8), 1009-1017.

Sinclair, C., Jackson, N. (Ed.), Oliver, M. (Ed.), Shaw, M. (Ed.), \& Wisdom, J. (Ed.) (2006). Developing students' creativity: Searching for an appropriate pedagogy. In Developing creativity in higher education: An imaginative curriculum (pp. 118-141).

Soule, H., \& Warrick, T. (2015). Defining $21^{\text {st }}$ century readiness for all students: What we know and how to get there. Psychology of Aesthetics, Creativity, and the Arts, 9(2), 178-186.

Snow, J. (1854). The cholera near goldensquare, and at Deptford. Medical Times and Gazette, 9, 321-322.

Sternberg, R. J. (Ed.). (1999). Handbook of creativity. Cambridge University Press.

Snyder, L. G., \& Snyder, M. J. (2008). Teaching critical thinking and problem-solving skills. The Journal of Research in Business Education, 50(2), 90.

Taft, R., \& Rossiter, J. R. (1966). The remote associates test: divergent or convergent thinking? Psychological Reports, 19(3), 13131314.

Terenzini, P. T., Springer, L., Pascarella, E. T., \& Nora, A. (1995). Influences affecting the development of students' critical thinking skills. Research in Higher Education, 36, 2339.https://doi.org/10.1007/BF02207765

Tips to pass a Watson Glaser Critical thinking test (n.d.). Assessment Training. https://www.assessment-training.com/blogs/tipsto-pass-a-watson-glaser-critical-thinking-test

Tsui, L. (2002). Fostering critical thinking through effective pedagogy: Evidence from four institutional case studies. The Journal of Higher Education, 73(6), 740-763.

Trilling, B., \& Fadel, C. (2009). 21st century skills: Learning for life in our times. John Wiley \& Sons. Van Laar, E., Van Deursen, A. J., Van Dijk, J. A., \& De Haan, J. (2017). The relation between 21stcentury skills and digital skills: A systematic literature review. Computers in Human Behavior, 72, 577-588.

Watkins, D., \& Regmi, M. (1995). Assessing approaches to learning in non-western cultures: A Nepalese conceptual validity study. Assessment \& Evaluation in Higher Education, 20(2), 203-212.

Wrigley, C., \& Straker, K. (2017). Design thinking pedagogy: The educational design ladder. Innovations in Education and Teaching International, 54(4), 374-38. 


\section{Acknowledgments}

This research was part of BUCSBIN (Building University Capacity to Support Business Incubation in Nepal) and funded by the Higher Education Institutional Cooperation Instrument (HEICl) of Finnish Government. 